\title{
Feeding, reproduction and toxin accumulation by the copepods Acartia bifilosa and Eurytemora affinis in the presence of the toxic cyanobacterium Nodularia spumigena
}

\author{
Betina Kozlowsky-Suzuki ${ }^{1,4, *}$, Miina Karjalainen ${ }^{2}$, Maiju Lehtiniemi $^{2}$, \\ Jonna Engström-Öst ${ }^{2}$, Marja Koski ${ }^{3,5}$, Per Carlsson ${ }^{4}$ \\ ${ }^{1}$ Department of Biology and Environmental Science, University of Kalmar, Kalmar 39182, Sweden \\ ${ }^{2}$ Finnish Institute of Marine Research, PO Box 33, 00931 Helsinki, Finland \\ ${ }^{3}$ Department of Ecology and Systematics, Division of Hydrobiology, Biocenter 3, University of Helsinki, PO Box 65, \\ 00014 Helsinki, Finland \\ ${ }^{4}$ Present address: Marine Biology, Lund University, Campus Helsingborg, Box 882, 25108 Helsingborg, Sweden \\ ${ }^{5}$ Present address: Danish Institute for Fisheries Research, Kavalergården 6, 2920 Charlottenlund, Denmark
}

\begin{abstract}
Feeding, reproduction and accumulation of cyanobacterial toxins by the calanoid copepods Acartia bifilosa and Eurytemora affinis were studied during a cruise in the northern Baltic Sea. The experiments were carried out using both mixtures of natural plankton communities, mixtures containing the toxic Nodularia spumigena, and diets containing only the toxic cyanobacterium. Both copepod species had a high survival and fed actively on $N$. spumigena, both as a single food source and when offered in mixtures. Feeding on N. spumigena resulted in the detection of nodularin equivalents in the animals. However, there was a negative relationship between the gross growth efficiency and accumulated toxins, which indicates that the food quality was not ideal, possibly related to a high metabolic cost to cope with ingested toxins. Overall low egg production rates by both species and low egg hatching success by $A$. bifilosa in natural seawater suggested that the copepods were food-limited in the environment. The presence of Brachiomonas submarina offered in combination with $N$. spumigena enhanced A. bifilosa egg production, but not egg hatching success. Egg hatching success was not affected by increasing concentrations of $N$. spumigena in the diet. Instead, lack of food seemed to be a more important factor. Similar responses by E. affinis populations from sites with different history of toxin occurrence suggest that tolerance to cyanobacterial toxins has evolved in the Baltic Sea. This has possibly been guaranteed by genetic exchange between the 2 populations. These results suggest that $N$. spumigena is not directly harmful to copepods if an alternative food source is available, even though reproduction is not sustained if the species is offered as a single diet. Moreover, even if both copepods might act as a link transporting toxins to higher trophic levels, a very small fraction of the estimated ingested toxin was found in the animals, therefore the relative importance of this pathway seems limited.
\end{abstract}

KEY WORDS: Nodularia spumigena · Acartia bifilosa $\cdot$ Eurytemora affinis $\cdot$ Feeding $\cdot$ Egg production · Nodularin - Toxin accumulation

\section{INTRODUCTION}

The occurrence of harmful algal blooms is worldwide, and in many cases toxins are produced. It is believed that the intensity of cyanobacterial blooms in the Baltic Sea, mainly formed by the nitrogen-fixing Aphanizomenon flos-aquae and Nodularia spumigena, has increased because of the eutrophication process (Finni et al. 2001). 
Most of the N. spumigena blooms and strains isolated from the Baltic Sea produce the hepatotoxic cyclic pentapeptide nodularin (Sivonen \& Jones 1999), which inhibits protein phosphatases (An \& Carmichael 1994, Honkanen et al. 1994, Ward et al. 1998).

Recent results suggest that cyanobacterial blooms in the Baltic Sea might play a more important role in the food web than previously assumed (Rolff 2000). It has been considered that feeding and/or reproduction by copepods feeding on toxic Nodularia spumigena are limited (Sellner et al. 1996, Koski et al. 1999, Engström et al. 2000). However, the depleted $\delta^{15} \mathrm{~N}$-isotopic signal found in pure cyanobacteria has been shown to be propagated to zooplankton, indicating either direct consumption of these cyanobacterial blooms or secondary consumption of bacterio-, phyto- and zooplankton using cyanobacterial nitrogen. Therefore, the role of cyanobacterial blooms as a food resource seems to be underestimated (Meyer-Harms et al. 1999) and should be re-evaluated (Rolff 2000).

Accumulation of toxins in the food web is likely to occur if toxic phytoplankton is consumed. In fact, experimental and field studies have demonstrated that microcystins (Watanabe et al. 1992, Kotak et al. 1996, Thostrup \& Christoffersen 1999, Ferrão-Filho et al. 2002), PSP toxins (White 1981, Turiff et al. 1995, Teegarden \& Cembella 1996, Turner et al. 2000), DSP toxins (Maneiro et al. 2000) and brevetoxins (Tester et al. 2000) accumulate in zooplankton. It has also been observed that phycotoxins can be transported via copepods to fish (Tester et al. 2000) and mysid shrimps (Engström-Öst et al. 2002). Nodularins and microcystins can also accumulate in mussels (Amorim \& Vasconcelos 1999, Sipiä et al. 2001a) and in fish that can later be consumed by man (Magalhães et al. 2001, Sipiä et al. 2001b).

We conducted feeding and reproduction experiments to investigate grazing, food selectivity and production of Acartia bifilosa and Eurytemora affinis in a range of conditions: from the natural community and mixtures containing the toxic Nodularia spumigena to diets containing only the toxic cyanobacterium. These conditions were set to observe the response of the animals exposed to increasing concentrations of N. spumigena, simulating different cyanobacterial bloom concentrations, and to see whether food selection occurs when other food types are also available. Further, we wanted to reveal whether the cyanobacterial toxin nodularin can accumulate in copepods, which could then act as a link transferring toxins to higher trophic levels. Toxic $N$. spumigena was also offered to 2 populations of $E$. affinis (from the Gulf of Finland and Bothnian Bay) to observe if these populations with a different history of exposure to the toxic cyanobacterium have different tolerance to nodularin.

\section{MATERIALS AND METHODS}

The experiments were conducted during a cruise on board RV 'Aranda' (Finnish Institute of Marine Research) in August 2000 in the northern Baltic Sea. The first experiment was performed in the Gulf of Finland $\left(60^{\circ} 15^{\prime} 01^{\prime \prime} \mathrm{N}, 27^{\circ} 48^{\prime} 20^{\prime \prime} \mathrm{E}\right)$ and the second experiment took place in Bothnian Bay $\left(64^{\circ} 18^{\prime} 12^{\prime \prime} \mathrm{N}\right.$, $\left.22^{\circ} 20^{\prime} 60^{\prime \prime} \mathrm{E}\right)$. The calanoid copepods Acartia bifilosa and Eurytemora affinis were used for the experiment in the Gulf of Finland, whereas in Bothnian Bay only E. affinis was abundant enough for the experiments. In the Gulf of Finland, copepods were incubated (1) with the $<100 \mu \mathrm{m}$ filtered natural plankton community (NC) in a concentration of $440 \mu \mathrm{g} \mathrm{C}^{-1}$, containing decaying toxic Nodularia spumigena filaments, (2) with a toxic culture of the same species $\left(\mathrm{N}_{;} 1281 \mu \mathrm{g} \mathrm{C}^{-1}\right)$, (3) with a mixture (ca. 1:1 as carbon) of $N$. spumigena and the green flagellate Brachiomonas submarina $\left(\mathrm{N}+\mathrm{B}_{\text {; }}\right.$ $1330 \mu \mathrm{g} \mathrm{C}^{-1}$ ) and (4) in GF/C-filtered seawater (FW). In Bothnian Bay, E. affinis was incubated (1) with the NC $\left(363 \mu \mathrm{g} \mathrm{C} \mathrm{l}^{-1}\right)$, (2) with a toxic culture of N. spumigena $\left(\mathrm{N}_{;} 907 \mu \mathrm{g} \mathrm{C} \mathrm{l}^{-1}\right)$, (3) with a mixture of both $\mathrm{N}$ and $\mathrm{NC}$ treatments $\left(\mathrm{N}+\mathrm{NC} ; 731 \mu \mathrm{g} \mathrm{Cl}^{-1}\right)$ and (4) in FW. The aim with the experiment in Bothnian Bay was to observe the survival and behaviour of copepods, which do not experience contact with the toxic cyanobacterium. Copepod feeding, survival, reproduction and accumulation of toxins were measured during both experiments.

Copepods from both areas were sampled with a $200 \mu \mathrm{m}$ net by vertical tows (from $50 \mathrm{~m}$ depth to the surface) and adult females were separated and placed in FW (Whatman GF/C) overnight. In addition, individuals (ca. 10 ind. sample ${ }^{-1}$ ) of both copepod species were picked and rinsed 3 times in FW and placed in 3 replicate tin capsules for particulate organic carbon (POC) analyses (see below). Natural seawater from both sites was pumped from the surface through a hose. In the Gulf of Finland, surface water temperature, chl $a$ and salinity were $17.5^{\circ} \mathrm{C}, 7.6 \mu \mathrm{g} \mathrm{l^{-1 }}$ and 4.1 PSU, respectively, and $16^{\circ} \mathrm{C}, 3.4 \mu \mathrm{g} \mathrm{l}^{-1}$ and $2.7 \mathrm{PSU}$ in Bothnian Bay (Finnish Institute of Marine Research unpubl. data). The nodularin-producing Nodularia spumigena strain AV1 was obtained from the culture collection of the University of Helsinki, Division of Microbiology (Lehtimäki et al. 1994, 2000), and grown in a modified Z8 medium (Hughes et al. 1958, Kotai 1972). The culture of the green flagellate Brachiomonas submarina was obtained from the Tvärminne Zoological Station, University of Helsinki, and grown in a modified Erd-Schreiber medium (Hällfors \& Hällfors 1992). Both cultures were monospecific, but non-axenic.

For the experiments, 20 to 25 female copepods of both species were separately placed in triplicate 1.21 
glass bottles with the different food suspensions. Control bottles (without copepods) were also incubated in triplicate for each treatment. The bottles were incubated on a plankton wheel $(0.5 \mathrm{rpm})$ at ambient temperature and on a day-night cycle, for the first $24 \mathrm{~h}$ to estimate feeding and then for an additional $48 \mathrm{~h}$ to estimate egg production. Plankton samples (20 to $100 \mathrm{ml}$ ) were collected at 0 and $24 \mathrm{~h}$ of the feeding experiment and preserved in acid Lugol's solution. After the $24 \mathrm{~h}$ feeding incubations, which should be time enough for small copepods to convert ingested food to eggs (Tester \& Turner 1990, Schmidt et al. 1998), copepods were gently collected onto a $100 \mu \mathrm{m}$ net, and live females were transferred into new food suspensions for the egg production rate (EPR) measurements. After the EPR experiments, females and eggs were gently collected onto 100 and $20 \mu \mathrm{m}$ nets, respectively. The number of eggs was counted and the females were collected for toxin analysis. These females were rinsed 3 times in FW, and individuals from each treatment were pooled together into 1 sample (ranging from 22 to 69 individuals). In addition, triplicates from each treatment of a known number of eggs (ca. 10) produced by Acartia bifilosa were separated and placed in petri dishes in filtered seawater to estimate egg hatching (EH) success. The number of hatched eggs was counted after $48 \mathrm{~h}$. Survival (SUR) of animals exposed to the different treatments was calculated as the percentage of live individuals after a certain incubation time $(24$ and $72 \mathrm{~h}$ after the feeding and EPR experiments, respectively) from the initial $(0 \mathrm{~h})$ number of females.

The concentration of phytoplankton and ciliates was determined at the start and at the end of the feeding experiments using an inverted microscope. Samples containing Nodularia spumigena filaments were sonicated for $10 \mathrm{~s}$ (Sonicator XL2020, Misonix) to decrease the length of the filaments and, therefore, increase the number of counting units (ca. 100 filaments in each sample). The number of $N$. spumigena cells per filament was then directly counted. Entire samples, or in the case of very dense taxa, diagonals were counted in sedimentation chambers of different volumes depending on the density of the filaments/cells, and at least 30 cells were measured to estimate the cell volume. Clearance rates (CR) and ingestion rates (IR) were estimated according to Frost (1972). IR of the different food types were converted to carbon by employing the volume to carbon conversion factor of 0.11 (Edler 1979), and the total ingestion rate (TIR) for each treatment was calculated as the sum of the ingestion rates of all food types in a diet. For the treatments in which mixtures of food were offered, clearance rates were used as a measure of food selection.
For the broadcast-spawning Acartia bifilosa, egg production was calculated as the number of eggs divided by the number of live females at the end of the incubation time. Egg cannibalism was considered not significant in the incubations since the number of empty eggs corresponded to the number of nauplii (Burdloff et al. 2002), which was corrected for in the EPR calculations. For the egg-carrying Eurytemora affinis, EPR was estimated according to: $P=N_{\mathrm{e}} /\left(N_{\mathrm{f}} D\right)$, where $P$ is the number of eggs produced by female per day, $N_{\mathrm{e}}$ and $N_{\mathrm{f}}$ are the number of eggs and females, respectively, at the end of the incubation time, and $D$ is the development time of the eggs. $D$ was calculated according to Andersen \& Nielsen (1997). E. affinis nauplii were observed in all the bottles. However, since it is likely that they were partly produced as an effect of the previous food sources in the natural environment (cf. hatching time of ca. $2 \mathrm{~d}$ at $16^{\circ} \mathrm{C}_{i}$ Andersen \& Nielsen 1997) they were not included in the calculations. This might have underestimated the EPR slightly. For each treatment, gross growth efficiency (GGE) was estimated by dividing the egg production by the TIR. Egg production was converted to carbon assuming an egg carbon content of $0.041 \mu \mathrm{g}$ for $A$. bifilosa and of $0.048 \mu \mathrm{g}$ for E. affinis (Kiørboe \& Sabatini 1995).

Triplicate aliquots (100 to $250 \mathrm{ml}$ ) of the different food suspensions, offered to the animals, were filtered onto pre-combusted Whatman GF/F filters for the determination of POC. The filters were placed in hydrogen peroxide-washed Eppendorf tubes and dried in an oven at $60^{\circ} \mathrm{C}$ overnight. Dry filters were folded in tin foils, and POC was determined using a CHN Analyser (NA 1500 NC, FISONS Instruments). The tin capsules containing the copepods from the start of the experiments were dried and analysed in the same way.

Triplicate aliquots (100 to $250 \mathrm{ml}$ ) of the different food suspensions were filtered (Whatman GF/F) for the determination of nodularin concentrations. Filters were extracted in $70 \%$ methanol:Milli-Q water in a sonicator bath (Bandelin, Sonorex TK 52) for $15 \mathrm{~min}$ and centrifuged (5417 C, Eppendorf) at $15338 \times g$ for $10 \mathrm{~min}$. The supernatant was filtered through a $0.2 \mu \mathrm{m}$ PTFE membrane and injected into the HPLC (high performance liquid chromatography) system (Hitachi/ Merk) equipped with an L-7455 photodiode array detector. The column was an ODS (3) Phenomenex (4.6 i.d. $\times 250 \mathrm{~mm}, 5 \mu \mathrm{m}$ particle size) and the mobile phase consisted of acetonitrile with $0.1 \% \mathrm{v} / \mathrm{v}$ TFA (trifluoroacetic acid) and Milli-Q water with $0.1 \%$ v/v TFA in a linear gradient at a flow rate of $1 \mathrm{ml} \mathrm{min}^{-1}$. Chromatograms were monitored at a fixed wavelength of $238 \mathrm{~nm}$ and UV spectra from 200 to $300 \mathrm{~nm}$. We employed a shorter version of the method described by 
Lawton et al. (1994) to analyse the samples from the Nodularia spumigena culture, in which the linear gradient increased from 35 to $47 \%$ acetonitrile after $12 \mathrm{~min}$. For the natural community samples, the gradient started at $35 \%$ acetonitrile and increased to $65 \%$ over $30 \mathrm{~min}$. The running time was increased in order to verify whether other compounds (i.e. microcystins) were present in the samples.

Samples containing the females were freeze-dried (Christ Alpha 2-4) and extracted with 100\% methanol. Sonication (Sonicator XL2020, Misonix) was carried out on ice until the tissues were homogenised. Samples were then centrifuged at $15338 \times g$ for $20 \mathrm{~min}$. The supernatant was divided into 2 equal portions and dried with gaseous $\mathrm{N}_{2}$. These 2 portions were resuspended with 50\% methanol:Milli-Q water and gradually diluted to $10 \%$ methanol:Milli-Q water. The samples were then analysed both by a fluorimetric protein phosphatase (PP1) assay (Fontal et al. 1999) and a direct competitive enzyme-linked immunosorbent assay (ELISA) (EnviroGard Microcystins Plate Kit). We used these 2 assays in order to obtain a more accurate toxin measurement, since the results obtained from each assay might differ when toxin variants and conjugates are present in the samples (An \& Carmichael 1994, Metcalf et al. 2000).

The data were tested for normality and homogeneity of variances, and log- or square root-transformed if those assumptions were not met. We used a multivariate analysis of covariance (MANCOVA) to separately assess the effect of the increase in the food concentration (POC in the food suspensions as a covariate) from the effect of the increase in the concentration of Nodularia spumigena (N. spumigena cell numbers in the food suspensions as a covariate) on the TIR, egg production and GGE of both copepod species in the Gulf of Finland (2-way MANCOVA), and of Eurytemora affinis (1-way MANCOVA) in Bothnian Bay. To assess whether feeding and reproductive responses of the 2 E. affinis populations differed according to their different history of toxin exposure, a 1-way MANCOVA was used considering the biomass of $N$. spumigena, offered as a sole food source, as a covariate. When significant differences were found, Tukey's a posteriori HSD test was used. The nonparametric Kruskal-Wallis $H$-test was used if the transformed data did not conform to the ANOVA assumptions. For a given treatment, differences between both copepods were tested using a $t$-test or Mann-Whitney $U$-test. We used a 2-way ANOVA (Gulf of Finland) and the $t$-test (Bothnian Bay) to assess whether CR and IR on $N$. spumigena differed when offered in mixtures or as a single diet. Whenever significant differences were detected, the sequential Bonferroni method was used to adjust the alpha values for multiple inferences
(Peres-Neto 1999). The alpha value was adjusted to account for the number of tests being performed to avoid a Type-I error, i.e. to reject the null hypothesis when it is actually true (Peres-Neto 1999).

\section{RESULTS}

\section{Total ingestion rate (TIR): the effect of food and Nodularia spumigena concentration}

Neither food nor Nodularia spumigena concentration had any effect on the TIR by either Eurytemora affinis or Acartia bifilosa (2-way MANCOVA: $p$ > 0.05) in the Gulf of Finland. In addition, there was no difference in the ingestion rates between the copepod species (2-way MANCOVA: p > 0.05). In Bothnian Bay, however, E. affinis ingestion rate increased with increasing food concentration and was significantly higher in the treatment with only $N$. spumigena, followed by the treatment in which $N$. spumigena was offered together with the natural community and by the natural community alone (1-way MANCOVA followed by Tukey's HSD: p < 0.05). However, when considering only the treatments containing N. spumigena, no effect of increasing concentration of the cyanobacterium was detected for this variable (1-way MANCOVA: $\mathrm{p}>0.05)$.

\section{Clearance (CR) and ingestion rates (IR) on the natural and offered prey items and food selection}

In the Gulf of Finland, the most abundant phytoplankton taxa in the natural community were: Aphanizomenon flos-aquae, Pyramimonas sp. and other small flagellates, Cryptomonas sp. and Anabaena sp. Filaments of Nodularia spumigena were also abundant, but CR and IR could not be determined for this species, since the filaments were in very low numbers even in the control bottles after the $24 \mathrm{~h}$ incubation. Ciliates $(<25 \mu \mathrm{m})$ seemed to be then the only food type eaten by both Acartia bifilosa and Eurytemora affinis in the natural community (Fig. 1a,b,d,e). E. affinis cleared and ingested these small ciliates at a higher rate than $A$. bifilosa did (CR: $t=-5.59$ and IR: $t=-6.03$; $\mathrm{n}=3$; $\mathrm{p}<0.01$ ). In Bothnian Bay, Pyramimonas sp., Monoraphidium sp., Cryptomonas sp. and Fragilaria sp. were the most abundant taxa. E. affinis fed on Fragilaria sp. and ciliates (Fig. 1c,f). Larger ciliates $(>25 \mu \mathrm{m})$ were cleared at a higher rate than the smaller ciliates $(<25 \mu \mathrm{m})$ and Fragilaria sp. (Fig. 1c).

CR and IR by both Acartia bifilosa and Eurytemora affinis on Nodularia spumigena did not differ, whether it was offered as the sole food or in combination with 
Brachiomonas submarina (2-way ANOVA: p > 0.05) (Fig. 1a,b,d,e). A. bifilosa had a higher CR on N. spumigena than on $B$. submarina, whereas $E$. affinis did not show any selection between these 2 food items (Fig. 1a,b). CR and IR on N. spumigena (Fig. 1c,f) by $E$. affinis in Bothnian Bay were higher when this food type was offered alone than in combination with the natural community (CR: $t=3.56$ and IR: $t=6.50 ; \mathrm{n}=3 ; \mathrm{p}<0.05$ ).

\section{Survival, reproduction and gross growth efficiency (GGE)}

Survival of Acartia bifilosa and Eurytemora affinis (from both the Gulf of Finland and Bothnian Bay) was

(a) Acartia bifilosa (Gulf of Finland)

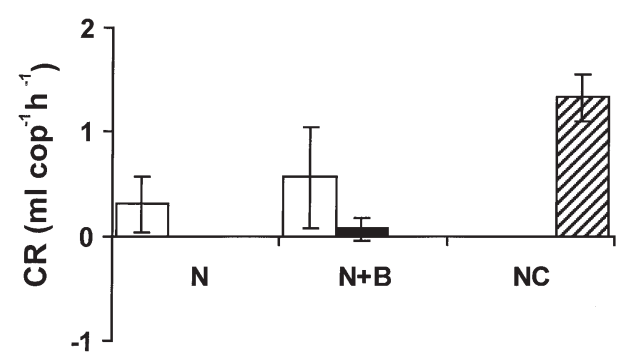

(b) Eurytemora affinis (Gulf of Finland)
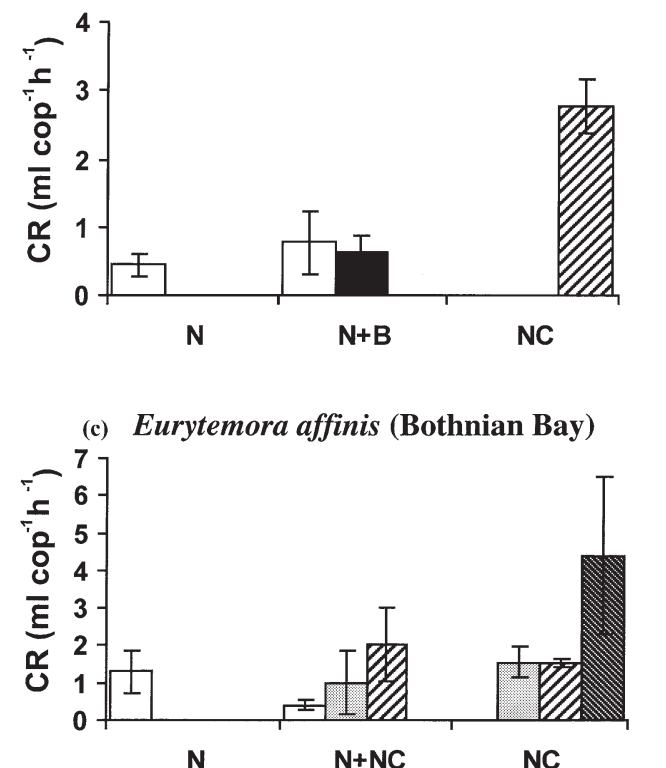

$\mathbf{N}$

NC generally high (Table 1). Although survival of both species tended to decrease with time in all treatments, there was no difference among treatments (Table 1 ; ANOVA; $\mathrm{p}>0.05$ ) and incubation time at both sites (Table 1; Mann-Whitney $U$-test or $t$-test; $\mathrm{p}>0.05$ ). In addition, survival did not differ between copepods in any treatment for each incubation time in the Gulf of Finland (Mann-Whitney $U$-test; $\mathrm{p}>0.05$ ).

In general, egg production in the Gulf of Finland was highest in the treatment containing a mixture of Nodularia spumigena and Brachiomonas submarina, followed by the natural community treatment and the one containing only the cyanobacterium, which did not differ from that in FW (Table 1). Increasing the food concentration resulted in an increase of the egg produc-

\section{(d) Acartia bifilosa (Gulf of Finland)}

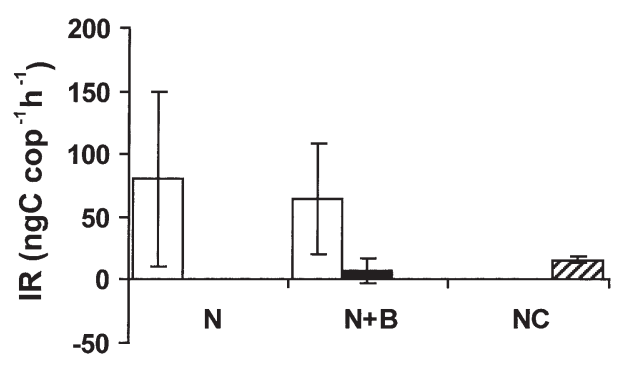

(e) Eurytemora affinis (Gulf of Finland)

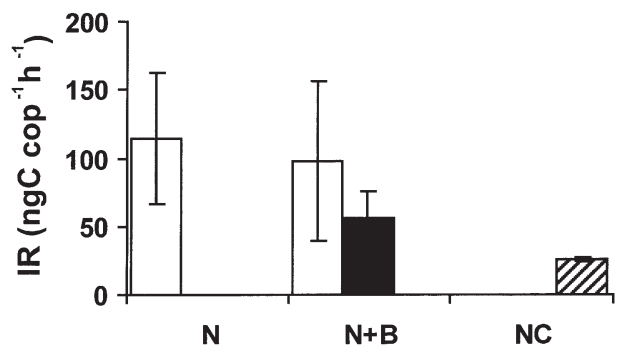

(f) Eurytemora affinis (Bothnian Bay)

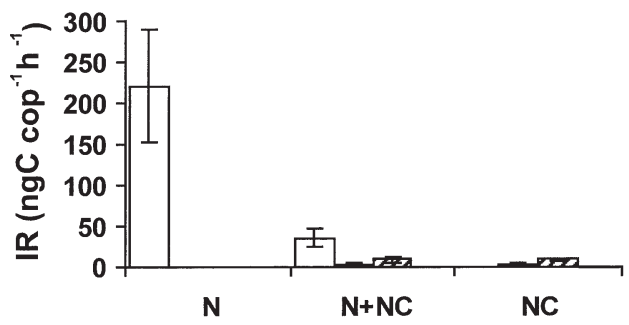

Fig. 1. Acartia bifilosa and Eurytemora affinis. Clearance rates (CR) ( $\left.\mathrm{ml} \mathrm{copepod}^{-1} \mathrm{~h}^{-1}\right)$ and ingestion rates (IR) (ng C copepod ${ }^{-1}$ $\mathrm{h}^{-1}$ ) by $A$. bifilosa and $E$. affinis for the different food items in the different treatments in the Gulf of Finland (a,b: CR; d,e: IR) and by $E$. affinis in Bothnian Bay $(\mathrm{c}, \mathrm{f})$. Columns and bars denote mean $\pm \mathrm{SD}$. $\mathrm{N}=$ Nodularia spumigena; $\mathrm{B}=$ Brachimonas submarina; $\mathrm{C}<25=$ ciliates $<25 \mu \mathrm{m} ; \mathrm{C}>25=$ ciliates $>25 \mu \mathrm{m} ; \mathrm{Fr}=$ Fragilaria sp.; $\mathrm{N}+\mathrm{B}=N$. spumigena $+B$. submarina, $\mathrm{N}+\mathrm{NC}=N$. spumigena + natural community, $\mathrm{NC}=$ natural community 
Table 1. Acartia bifilosa and Eurytemora affinis mean (SD) total ingestion rate (TIR, $\mathrm{ng} \mathrm{C}$ copepod ${ }^{-1} \mathrm{~h}^{-1}$ ), survival (SUR, $\left.\%\right)$ at 24 and $72 \mathrm{~h}$, egg production rate (EPR, number of eggs female ${ }^{-1} \mathrm{~d}^{-1}$ ), gross growth efficiency (GGE, \%) and egg hatching success $(\mathrm{EH}, \%)$ in the Gulf of Finland (GF) and in Bothnian Bay (BB), incubated in different treatments: $\mathrm{N}=$ Nodularia spumigena; $\mathrm{N}+\mathrm{B}=$ $N$. spumigena + Brachiomonas submarina; $\mathrm{NC}=$ natural community; $\mathrm{N}+\mathrm{NC}=\mathrm{N}$. spumigena + natural community; $\mathrm{FW}=$ filtered seawater, NS $=$ not significant

\begin{tabular}{|c|c|c|c|c|c|}
\hline GF & $\mathrm{N}$ & $\mathrm{N}+\mathrm{B}$ & $\mathrm{NC}$ & FW & ANOVA \\
\hline \multicolumn{6}{|l|}{ A. bifilosa } \\
\hline TIR & $80.16(69.22)$ & 71.64 (31.38) & $15.60(2.57)$ & - & \\
\hline SUR $24 \mathrm{~h}$ & $86.66(14.43)$ & $92.96(6.11)$ & $94.91(0.15)$ & $84.09(5.56)$ & $3.40 \mathrm{NS}^{\mathrm{c}}$ \\
\hline SUR $72 \mathrm{~h}$ & $51.66(35.47)$ & $75.74(3.94)$ & $65.96(12.20)$ & $59.11(15.31)$ & $1.99 \mathrm{NS}^{\mathrm{c}}$ \\
\hline EPR & $1.50(0.89)$ & $5.21(1.82)$ & $1.13(0.82)$ & 0.59 (0.17) & \\
\hline GGE & 3.20 (1.91) & $14.55(5.10)$ & $14.56(10.52)$ & - & \\
\hline $\mathrm{EH}$ & $20(10)$ & $16(15)$ & $26(20)$ & 0 & \\
\hline \multicolumn{6}{|l|}{ E. affinis } \\
\hline TIR & $114.02(48.20)$ & $152.42(45.45)$ & $25.87(1.43)$ & - & \\
\hline SUR $24 \mathrm{~h}$ & $82.27(11.75)$ & $95.15(4.76)$ & 100 & $83.33(20.81)$ & $5.21 \mathrm{NS}^{\mathrm{c}}$ \\
\hline SUR $72 \mathrm{~h}$ & $72.05(7.08)$ & $82.83(7.01)$ & $93.93(6.94)$ & $68.00(20.29)$ & $5.85 \mathrm{NS}^{\mathrm{c}}$ \\
\hline EPR & $0.52(0.47)$ & $2.41(0.55)$ & $0.99(0.64)$ & $0.48(0.41)$ & \\
\hline GGE & $0.92(0.84)$ & $3.16(0.72)$ & $7.71(4.98)$ & - & \\
\hline $\mathrm{BB}$ & $\mathrm{N}$ & $\mathrm{N}+\mathrm{NC}$ & $\mathrm{NC}$ & FW & ANOVA \\
\hline \multicolumn{6}{|l|}{ E. affinis } \\
\hline TIR & $220.86(68.26)^{\mathrm{C}}$ & $47.50(12.26)$ & $14.34(1.71)$ & - & \\
\hline SUR $24 \mathrm{~h}$ & $84.67(5.76)$ & $91.26(2.86)$ & $93.59(5.62)$ & $90.22(8.03)$ & $1.24 \mathrm{NS}^{\mathrm{K}}$ \\
\hline SUR $72 \mathrm{~h}$ & $82.92(8.52)$ & $91.26(2.86)$ & $90.38(8.43)$ & $77.20(17.51)$ & $1.15 \mathrm{NS}^{\mathrm{b}}$ \\
\hline EPR & $1.99(2.42)$ & $2.58(0.84)$ & $0.61(0.30)$ & $1.32(0.66)$ & \\
\hline GGE & $1.81(2.19)$ & $10.86(3.54)$ & $8.62(4.28)$ & - & \\
\hline
\end{tabular}

tion by Acartia bifilosa only in the treatment containing a mixture of $N$. spumigena and $B$. submarina (2-way MANCOVA followed by Tukey's HSD: p < 0.05). However, increasing the biomass of N. spumigena resulted in a significant decrease in the egg production by $A$. bifilosa (2-way MANCOVA followed by Tukey's HSD: $\mathrm{p}<0.05)$. Eggs produced by $A$. bifilosa hatched in all treatments, except for the individuals kept in FW (Table 1). Egg hatching success was very low and did not differ significantly among treatments (Table 1); no difference was observed with an increase in the total food concentration (1-way MANCOVA: $\mathrm{p}>$ 0.05 ) or the N. spumigena biomass (1-way MANCOVA: $\mathrm{p}>0.05)$. In Bothnian Bay, E. affinis egg production did not differ among treatments (Table 1). Neither an increase in food concentration nor the N. spumigena biomass affected the egg production in the experiments performed at this site (1-way MANCOVA: $p$ > 0.05).

In the Gulf of Finland, the GGE of Eurytemora affinis was higher in the natural community than in the Nodularia spumigena treatment (Table 1; 2-way MANCOVA followed by Tukey's HSD: $\mathrm{p}<0.05)$, while it did not differ for Acartia bifilosa (2-way MANCOVA: p > 0.05). However, the GGE of $A$. bifilosa was higher while feeding on N. spumigena and Brachiomonas submarina than when feeding only on the cyanobac- terium (2-way MANCOVA followed by Tukey's HSD: $\mathrm{p}<0.05)$. Regarding total food concentration, there was no difference between the GGE values for the 2 copepod species (2-way MANCOVA: p > 0.05). However, $A$. bifilosa had higher GGE than E. affinis when the biomass of $N$. spumigena decreased (2-way MANCOVA followed by Tukey's HSD: $\mathrm{p}<0.05)$. In Bothnian Bay, GGE was similar in the treatment with N. spumigena and the natural community and in the natural community alone, which was significantly higher than in the $N$. spumigena treatment (Table 1; 1-way MANCOVA followed by Tukey's HSD: p < 0.05) However, when the biomass of $N$. spumigena was used as a covariate, the values did not differ between these treatments, and this pattern could not be confirmed (1-way MANCOVA: $p$ > 0.05).

\section{Comparison of the Eurytemora affinis populations from the Gulf of Finland and Bothnian Bay}

There was no difference on the feeding (TIR) (1-way MANCOVA: $p>0.05$ ) and reproductive responses (EPR and GGE) (1-way MANCOVA: p > 0.05) between the 2 Eurytemora affinis populations after exposure to the toxic cyanobacterium. 
Table 2. Nodularin concentrations $\left(\mathrm{ng} \mathrm{m}^{-1}\right.$ ) in the food suspensions for the different treatments (analysed by HPLC, mean [SD]) and nodularin equivalents (ng copepod ${ }^{-1}$ ) in Acartia bifilosa and Eurytemora affinis in the Gulf of Finland (GF) and in Bothnian Bay (BB) analysed by the protein phosphatase (PP1) assay and the ELISA. Other abbreviations as in Table 1

\begin{tabular}{|lcccc|}
\hline GF & $\mathrm{N}$ & $\mathrm{N}+\mathrm{B}$ & $\mathrm{NC}$ & FW \\
\hline Food suspension & $2.39(0.46)$ & $0.83(0.13)$ & $\mathrm{ND}$ & - \\
A. bifilosa & PP1/ELISA & PP1/ELISA & PP1/ELISA & ND/ND \\
E. affinis & $0.013 / 0.011$ & $0.010 / 0.006$ & $0.008 / 0.001$ & ND/ND \\
BB & $0.024 / 0.011$ & $0.014 / 0.006$ & $\mathrm{NC}$ & FW \\
\hline Food suspension & $\mathrm{N}$ & $\mathrm{N}+\mathrm{NC}$ & $\mathrm{ND}$ & - \\
E. affinis & $1.92(0.15)$ & 0.25 & PP1/ELISA & PP1/ELISA \\
& PP1/ELISA & PP1/ELISA & $0.001 / \mathrm{ND}$ & $0.001 / \mathrm{ND}$ \\
\hline
\end{tabular}

\section{Toxin accumulation}

Nodularin was found in all the treatments containing cultured Nodularia spumigena but was not detected in the natural community (Table 2). However, phytoplankton toxin measurements from samples collected in the Gulf of Finland during the same time as the present study ranged from 0.2 to $9.0 \mu \mathrm{g}$ nodularin $\mathrm{g}^{-1} \mathrm{DW}$ (Finnish Institute of Marine Research unpubl. data). Moreover, nodularin equivalents were detected in Eurytemora affinis (Fig. 2a,b, Table 2) from the Gulf of Finland by both PP1 and ELISA.

Nodularin equivalents measured by the PP1 assay were up to 5 times higher than those detected by the ELISA. Eurytemora affinis had a higher toxin content than Acartia bifilosa when analysed by the PP1 assay, but the concentrations were similar when the ELISA was used. The highest toxin concentrations in the copepods were found (both PP1 assay and ELISA) when the copepods were incubated with only the toxic Nodularia spumigena, followed by the animals grazing on both $N$. spumigena and Brachiomonas submarina (Gulf of Finland) and those offered the toxic N. spumigena and the natural community in combination (Bothnian Bay).

There was a linear positive relationship between the nodularin equivalents detected by the PP1 assay in the copepods and their IR of Nodularia spumigena cells (data from all treatments; Fig. 3). There was also a linear negative relationship between the GGE and the nodularin equivalents detected by the PP1 assay in the copepods (data from all treatments; Fig. 4).

Nodularin equivalents were also detected by the PP1 and the ELISA in Eurytemora affinis that had been incubated with both the natural community and the FW from the Gulf of Finland (Table 2). However, in Bothnian Bay, nodularin equivalents in the copepods from those treatments were only detected by the PP1 assay.

\section{DISCUSSION}

\section{Feeding and reproduction}

The TIR of both Acartia bifilosa and Eurytemora affinis tended to increase with increasing food concentration, which could indicate food limitation in the environment. In the natural community, both $A$. bifilosa and $E$. affinis had comparable CR and IR on ciliates, as recently reported (Koski et al. 2002). Moreover, both copepod species fed selectively on ciliates even when phytoplankton was available, in accordance with the
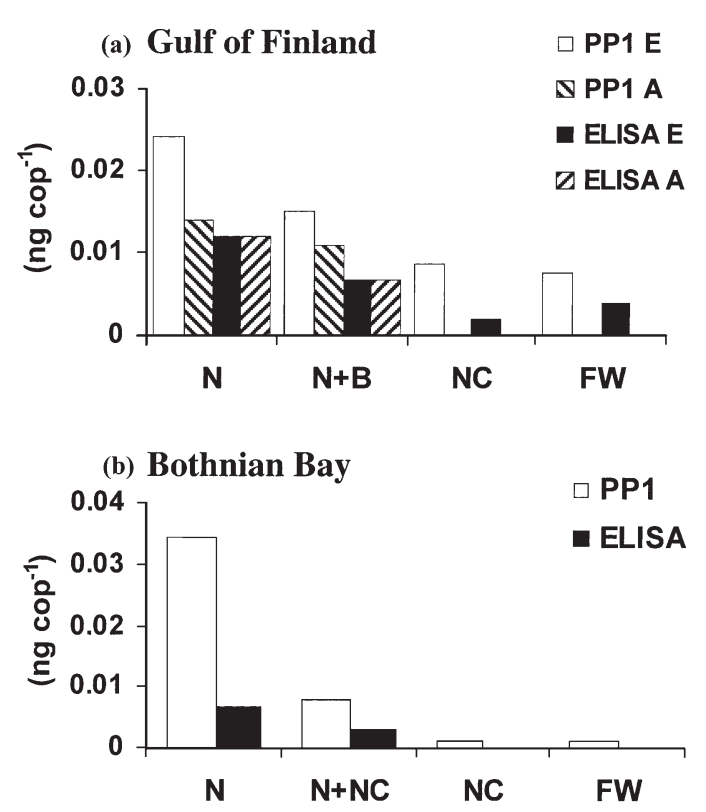

Fig. 2. Acartia bifilosa and Eurytemora affinis. Nodularin equivalents (ng copepod ${ }^{-1}$ ) detected by the protein phosphatase (PP1) assay and the ELISA in E. affinis (PP1 E, ELISA E) and A. bifilosa (PP1 A, ELISA A) in the Gulf of Finland (a) and in E. affinis (PP1, ELISA) in Bothnian Bay (b). Abbreviations as in Fig. 1. FW = filtered seawater 


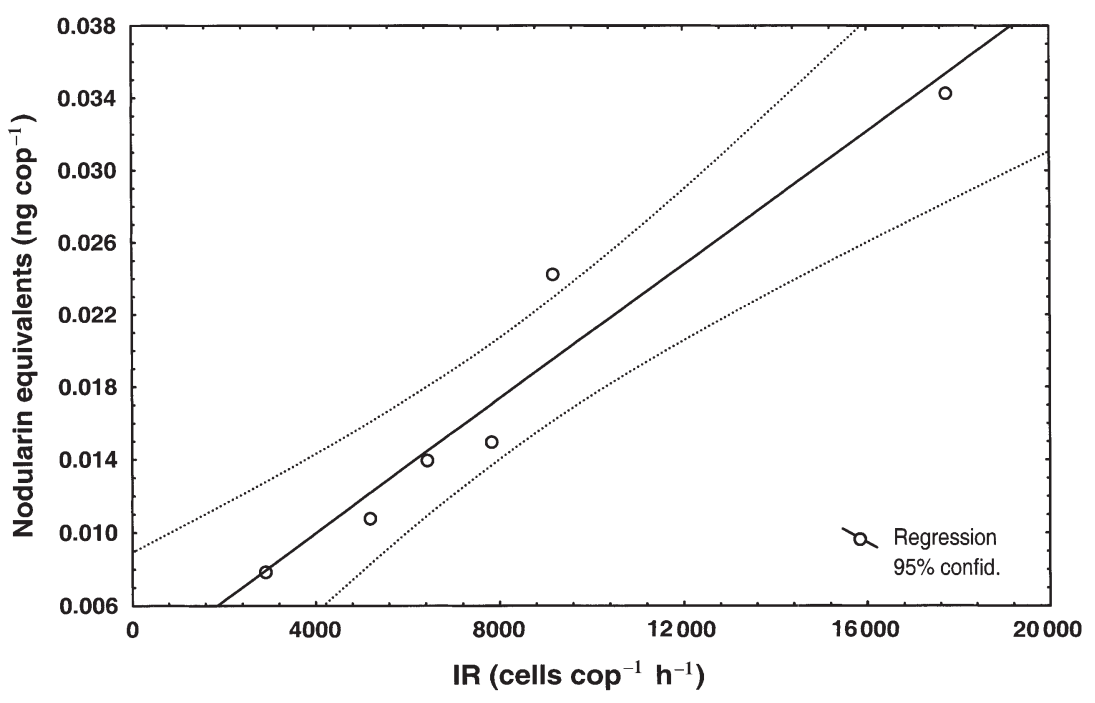

Fig. 3. Relationship between ingestion rates (IR, Nodularia spumigena cells copepod $^{-1} \mathrm{~h}^{-1}$ ) and nodularin equivalents in copepods (measurements done by the protein phosphatase assay [PP1]) feeding on the different treatments. PP1 = $0.00257+210^{-6} \times$ cells; $\mathrm{R}^{2}=0.93 ; \mathrm{n}=6 ; \mathrm{p}=0.0014$

In grazing experiments performed during different phases of a cyanobacteria bloom after the addition of a high biomass of cultured toxic Nodularia spumigena to a natural community, Koski et al. (2002) found very high IR for both Acartia bifilosa (23 $\mu \mathrm{g} \mathrm{C}$ ind. ${ }^{-1} \mathrm{~d}^{-1}$ ) and Eurytemora affinis $\left(10 \mu \mathrm{g} \mathrm{C}\right.$ ind..$\left.^{-1} \mathrm{~d}^{-1}\right)$ on cyanobacteria. These authors suggested that the high ingestion of cyanobacteria was due to compensatory feeding, i.e. the copepods increased their feeding rates in order to compensate for the low food quality of the cyanobacteria. Non-satiated feeding by A. clausi on the PSPproducing dinoflagellates Alexandrium lusitanicum (Dutz 1998) and A. minutum (Frangópulos et al. 2000) has also been suggested as a means to compensate for an enhanced energy expenditure of copepods to cope with ingested toxins.

In our study, the high IR on Nodularia spumigena was only reflected in very low GGE values; i.e. high IR of the toxic

results obtained by Stoecker \& Egloff (1987) and Koski et al. (2002). Ciliates may often be an important part of the diet of copepods in nature, not only quantitatively but also qualitatively, since they may contain appreciable amounts of polyunsaturated fatty acids (PUFAs) (Stoecker \& McDowell Capuzzo 1990).

Both Acartia bifilosa and Eurytemora affinis fed actively on the toxic Nodularia spumigena even when other food items were present. Although previous studies have demonstrated that $A$. bifilosa (Sellner et al. 1996, Engström et al. 2000) and E. affinis (Sellner et al. 1996) graze poorly on the toxic cyanobacterium, a recent study supports the results presented here (Koski et al. 2002). It has been suggested that observed high feeding by Acartia spp. and Temora longicornis on cyanobacteria can be caused by a high cyanobacteria biomass and/or that the bloom is in a later phase (Meyer-Harms et al. 1999). However, this was not found by Koski et al. (2002) since a higher feeding rate on cyanobacteria by calanoid copepods was observed especially when the bloom was actively growing, and not in a later phase. Nevertheless, it seems that the feeding activity by calanoid copepods increases at a high cyanobacteria biomass (Meyer-Harms et al. 1999, Koski et al. 2002).

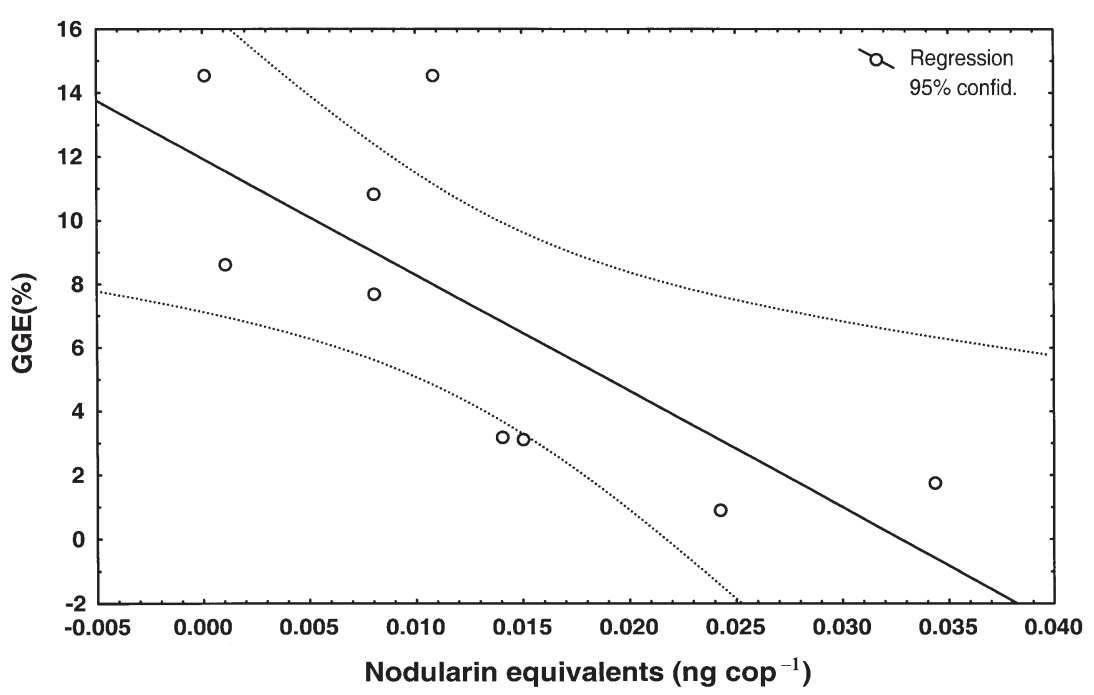

Fig. 4. Relationship between the nodularin equivalents in copepods (measurements done by the protein phosphatase assay [PP1]) and the gross growth efficiency, $\mathrm{GGE}=11.93-364.5 \times \mathrm{PP} 1 ; \mathrm{R}^{2}=0.56 ; F_{1,7}=9.02 ; \mathrm{n}=9 ; \mathrm{p}=0.019$ 
and/or the need to cope with toxins (Dutz 1998). We have observed a decrease in the GGE values with an increase of the toxin concentration in the copepods, suggesting that the copepods allocate more energy to detoxification than to reproduction when they ingest more toxins, as suggested by Dutz (1998).

The number of eggs produced by Eurytemora affinis in the presence of Nodularia spumigena alone was low and not different from that produced in FW, while the addition of Brachiomonas submarina tended to increase egg production. Similar responses have previously been reported (Sellner et al. 1996, Koski et al. 1999). Acartia bifilosa egg production was in the same range or lower than previously reported for this species (Sellner et al. 1996, Koski \& Kuosa 1999, Koski et al. 2002) and was highest in the $N$. spumigena with $B$. submarina treatment.

The addition of Brachiomonas submarina also increased the GGE of Acartia bifilosa significantly, emphasising the adequate nutritious status of this green flagellate (Sellner et al. 1996, Koski et al. 1999). Green algae have, in general, small amounts of PUFAs (Ahlgren et al. 1992, Brown et al. 1997), which are important for zooplankton reproduction (MüllerNavarra et al. 2000). However, egg production by $A$. bifilosa feeding on B. submarina (Sellner et al. 1996) is higher than reported elsewhere (Schmidt et al. 1998, Yoon et al. 1998, Castro-Longoria \& Williams 1999, Koski \& Kuosa 1999). Addition of B. submarina to $<100 \mu \mathrm{m}$ FW increased the C (carbon) and N (nitrogen) contents of Eurytemora affinis eggs even when no increase was detected in the females (Koski 1999). Furthermore, we have observed that the pellet production rate by $E$. affinis feeding on $B$. submarina, which corresponded to rates of other copepods feeding on good food, was significantly higher than on natural community or N. spumigena diets (Lehtiniemi et al. 2002).

The egg hatching success of Acartia bifilosa was low and variable in all treatments. This could have been related to the low EPR (Tang \& Dam 2001), which in turn could have been associated with nutritional limitation (Jónasdóttir \& Kiørboe 1996). In our study, the increase in food quantity only led to an increase in the egg production of A. bifilosa when Brachiomonas submarina was present. However, this positive effect on egg production was not reflected by any increase in hatching success. Food sources that are apparently adequate for egg production may not necessarily be sufficient for both egg viability and hatching, indicating that these variables can be decoupled (Turner et al. 2001). Eurytemora affinis egg hatching success from the Baltic Sea has been reported to range from 0 to $87 \%$ and shown to be inhibited by toxic Nodularia spumigena, suggesting the presence of inhibitory compounds (Koski et al. 1999). However, no inhibition of the egg hatching success of $A$. bifilosa was observed in the present study, since hatching did not decrease with increasing biomass of the toxic $N$. spumigena after $72 \mathrm{~h}$ exposure. Despite the low number of eggs used in the hatching experiment and the low viability of eggs in the natural community treatment, the lack of food seemed to be a more important factor in decreasing egg hatching success than an inhibition by $N$. spumigena, since no eggs hatched when the females were kept in filtered seawater for $72 \mathrm{~h}$, while eggs hatched in all the other treatments.

\section{Tolerance to cyanobacterial toxins}

Both Eurytemora affinis populations (from the Gulf of Finland and Bothnian Bay) fed actively and not differently on Nodularia spumigena. Furthermore, no difference was detected between these populations for their reproductive responses after feeding on the toxic cyanobacterium. Even though toxic $N$. spumigena blooms have never been recorded in Bothnian Bay (G. Hällfors pers. comm.), there was no significant effect of the toxic $N$. spumigena on the survival, feeding and reproduction by $E$. affinis from this site.

Adaptation and resistance to toxins seem to be dependent on the history of toxin exposure (Kurmayer \& Jüttner 1999, Bricelj et al. 2000, Nandini 2000, Colin \& Dam 2002). Colin \& Dam (2002) suggested that differential resistance to toxic Alexandrium spp. by populations of Acartia hudsonica has occurred due to latitudinal distribution of the toxic algae and copepods. They observed some degree of tolerance to Alexandrium spp. by an $A$. hudsonica population in a region where blooms have occurred in the past (much less frequent and less toxic than in northern regions) and suggested that genetic exchange might have contributed for this tolerance due to the proximity of those populations. Even if blooms of toxic Nodularia spumigena do not occur in Bothnian Bay (G. Hällfors pers. comm.), the proximity of Bothnian Bay to the Bothnian Sea, where toxic blooms occur frequently (Kononen et al. 1993), might contribute to the genetic exchange between the 2 copepod populations. A genetic exchange between the copepod populations would guarantee some tolerance to cyanobacterial toxins also in the Bothnian Bay population. As suggested by Reinikainen et al. (2002), resistance to nodularin has probably evolved in the Baltic Sea, where cyanobacterial blooms have been reported to occur for at least $7000 \mathrm{yr}$ (Bianchi et al. 2000).

\section{Toxin accumulation}

Both Acartia bifilosa and Eurytemora affinis accumulated cyanobacterial toxins. Values found in E. affi- 
nis were in the same range as previously observed for this species (Engström-Öst et al. 2002, Lehtiniemi et al. 2002).

Both Acartia bifilosa and Eurytemora affinis contained the highest toxin concentrations when they were incubated with only the toxic Nodularia spumigena, followed by the animals fed the food mixtures containing $N$. spumigena, which reflects the ingestion of the toxic food. Such a relationship was significant when measured by the PP1 assay (Fig. 3). Nodularin equivalents measured by the PP1 assay were higher in E. affinis than in A. bifilosa within the same treatment, whereas they were found in similar ranges when analysed by the ELISA. Even though there was no significant difference between the IR, E. affinis ingested on average 1.42 and 1.51 times more $N$. spumigena cells than $A$. bifilosa did in the $\mathrm{N}$ and N+B treatments, respectively. Accordingly, toxin equivalents for both treatments measured by the PP1 assay were 1.73 and 1.38 times higher in E. affinis.

Although Nodularia spumigena filaments were present in the Gulf of Finland, and toxin measurements ranged from 0.2 to $9.0 \mu \mathrm{g}$ nodularin $\mathrm{g}^{-1} \mathrm{DW}$ in this area (Finnish Institute of Marine Research unpubl. data), copepod clearance and ingestion rates could not be estimated for $N$. spumigena in the natural community. Therefore, we cannot infer the relevance of the consumption of $N$. spumigena in the natural community. However, we suggest that the toxin equivalents detected in Eurytemora affinis incubated with the natural community indicate that even when other food types are available, cyanobacteria are consumed (Meyer-Harms et al. 1999).

Nodularin equivalents were detected in the individuals kept in FW from the Gulf of Finland by both the PP1 and the ELISA assays. This could indicate that Eurytemora affinis is capable of degrading/detoxifying toxins, but with some delay after ingestion. This process could vary depending on the conditions (e.g. starvation or transfer to a non-toxic food source) to which the animals are subjected after exposure to a toxic diet (Svensson 2000).

The PP1 assay gave values up to 5 times higher than those detected by the ELISA, which has also been observed before (Engström-Öst et al. 2002, Lehtiniemi et al. 2002). Protein phosphatases can be inhibited by a series of different compounds (An \& Carmichael 1994, Honkanen et al. 1994), while in general, the antibodies in the ELISA tend to recognise and cross-react only with microcystins, nodularins and closely related molecules. However, cross-reaction with the ELISA antibodies with less toxic (measured by a protein phosphatase assay) microcystin-LR conjugates, with similar affinities to that of microcystin-LR, has been demonstrated (Metcalf et al. 2000). On the other hand, micro- cystin and nodularin variants, which inhibited protein phosphatase and showed toxicity in mouse bioassay, did not cross-react with ELISA antibodies (An \& Carmichael 1994). According to these authors, a combination of both assays will prove useful in detecting microcystins and nodularins in the environment. Therefore, whenever possible, both methods should be used.

\section{Balance between the estimated ingested and egested toxins for Eurytemora affinis: where did the toxin end up?}

Without considering any possible losses of nodularin, the amount of nodularin equivalents measured in 1 individual copepod should be the balance between the amount ingested and the amount egested with faecal pellets over a certain time.

Assuming that 1 Eurytemora affinis adult female ingests ca. 216000 Nodularia spumigena cells (average $24 \mathrm{~h}$ ingestion rate for E. affinis in the Gulf of Finland) with a toxin content of $0.13 \mathrm{pg} \mathrm{cell}^{-1}$ (measured by HPLC), the amount of toxin ingested in our study during $24 \mathrm{~h}$ should equal $28 \mathrm{ng}$ copepod $^{-1}$.

In another study performed during the same cruise, the content of nodularin equivalents in the pellets produced by Eurytemora affinis, feeding on the same Nodularia spumigena strain as in the present experiment, was quantified (Lehtiniemi et al. 2002). During this study, E. affinis females produced $10.38 \pm 5.90$ pellets during $24 \mathrm{~h}$ (in a food suspension containing $876 \mu \mathrm{g} \mathrm{Cl}^{-1}$ of $N$. spumigena). This number of pellets contains, at the most, $0.0067 \mathrm{ng}$ of nodularin equivalents (measured by the ELISA and by a PP1 assay). In the present study, the $N$. spumigena treatment contained $1281 \mu \mathrm{g} \mathrm{C}^{-1}$, which can be considered similar to the conditions mentioned above, since in both cases the food concentrations were very high and above saturated ingestion (Kiørboe et al. 1985). Therefore, we can assume that the toxin egested in the faecal pellets by a female during $24 \mathrm{~h}$ in our study should be in the same range ( $0.0067 \mathrm{ng}$ of nodularin equivalents). Thus, the amount of toxin equivalents found in 1 copepod after $24 \mathrm{~h}(0.02 \mathrm{ng})$ is less than $0.1 \%$ of the ingested toxin minus the egested: $(0.02 /[28-0.0067]) \times 100$. Low retention of ingested toxins in tissues of zooplankton feeding on PSP-producing algae, ranging from $<5 \%$ (Teegarden \& Cembella 2000) to $10-36 \%$ (White 1981), have also been observed.

'Sloppy feeding' by zooplankton (Roy et al. 1989), biodegradation of toxins (Jones et al. 1994, Matthiensen et al. 2000), toxin detoxification/metabolisation (Pflugmacher et al. 1998) and low toxin recovery (Sipiä et al. 2001b) can be suggested to explain the lack of corre- 
spondence between the estimated amount of ingested toxin to that actually found in Eurytemora affinis.

\section{CONCLUSIONS}

Acartia bifilosa and Eurytemora affinis did not avoid the toxic Nodularia spumigena. Both grazers fed actively on the cyanobacterium, survived, and even sustained the production of eggs when other food items were offered. However, the negative relationship between accumulated toxins and the GGE values indicates that the food quality was not ideal, possibly related to high metabolic costs to cope with ingested toxins. Food limitation instead of inhibition by toxic compounds seemed to be a more important factor for A. bifilosa egg hatching success. High concentrations of dissolved cyanobacterial toxins have been shown to have no negative effect on the hatching success of $E$. affinis (Reinikainen et al. 2002). Thus, in natural bloom situations, the low quality of the cyanobacterium, i.e. lack of essential components and/or metabolic costs to cope with toxins, seems more likely to limit the secondary productivity of copepods. No difference could be detected between the E. affinis populations from the 2 sites, suggesting evolved tolerance to toxins, possibly guaranteed by genetic exchange. Both copepods ingested the toxic $N$. spumigena and toxins were found in their tissues. However, at least for E. affinis, only a very small fraction of the calculated ingested toxin could be found in the animals. Thus, even though these grazers might act as a link transferring toxins to higher trophic levels, the relative importance of this indirect pathway seems limited. Further studies are needed in order to investigate the possible mechanisms by which only low amounts of toxin are detected in the grazers compared to the estimated difference between ingested and egested toxin. The relative importance of different zooplankton species in the transport of toxins to higher trophic levels should also be addressed. In addition, long-term experiments should be conducted to assess the effects of toxic cyanobacteria on physiological processes of copepods.

Acknowledgements. We would like to thank the personnel of the Finnish Institute of Marine Research for the use of the facilities, help during the cruise on RV 'Aranda' and for providing valuable information. We also thank E. Granéli for the use of the laboratory facilities at the University of Kalmar, C. Esplund for performing the particulate carbon analyses, S. Repka and K. Sivonen for providing the cyanobacterial strain (AV1) used in the experiments, W. Stolte and C. Ward for discussions on toxin analysis and 4 anonymous referees for helpful comments on the manuscript. This study was financed by CNPq (The Brazilian National Council for Research), MISTRA (Swedish Foundation for Strategic Environmental Research), BIOHAB ('Biological control of harmful algal blooms in Euro- pean coastal waters: role of eutrophication' contract: EVK3CT99-00015), the Academy of Finland and the Maj and Tor Nessling Foundation.

\section{LITERATURE CITED}

Ahlgren G, Gustafsson IB, Boberg M (1992) Fatty acid content and chemical composition of freshwater microalgae. J Phycol 28:37-50

Amorim A, Vasconcelos V (1999) Dynamics of microcystins in the mussel Mytilus galloprovincialis. Toxicon 37:1041-1052

An J, Carmichael WW (1994) Use of a colorimetric protein phosphatase inhibition assay and enzyme linked immunosorbent assay for the study of microcystins and nodularins. Toxicon 32:1495-1507

Andersen CM, Nielsen TG (1997) Hatching rate of the eggcarrying estuarine copepod Eurytemora affinis. Mar Ecol Prog Ser 160:283-289

Bianchi TS, Engelhaupt E, Westman P, Andrén T, Rolff C, Elmgren R (2000) Cyanobacterial blooms in the Baltic Sea: natural or human-induced? Limnol Oceanogr 45:716-726

Bricelj VM, Twarog BM, MacQuarrie SP, Chang P, Trainer VL (2000) Does the history of toxin exposure influence bivalve population responses to PSP toxins in Mya arenaria? I. burrowing and nerve responses. J Shellfish Res 19:635

Brown MR, Jeffrey SW, Volkman JK, Dunstan GA (1997) Nutritional properties of microalgae for mariculture. Aquaculture 151:315-331

Burdloff D, Gasparini S, Villate F, Uriarte I, Cotano U, Sautour B, Etcheber H (2002) Egg production of the copepod Acartia bifilosa in 2 contrasting European estuaries in relation to seston composition. J Exp Mar Biol Ecol 274:1-17

Castro-Longoria E, Williams JA (1999) The production of subitaneous and diapause eggs: a reproductive strategy for Acartia bifilosa (Copepoda: Calanoida) in Southampton Water, UK. J Plankton Res 21:65-84

Colin SP, Dam HG (2002) Latitudinal differentiation in the effects of the toxic dinoflagellate Alexandrium spp. on the feeding and reproduction of populations of the copepod Acartia hudsonica. Harmful Algae 1:113-125

DeMott WR (1998) Utilization of a cyanobacterium and a phosphorus-deficient green alga as complementary resources by daphnids. Ecology 79:2463-2481

DeMott WR (1999) Foraging strategies and growth inhibition in 5 daphnids feeding on mixtures of a toxic cyanobacterium and a green alga. Freshw Biol 42:263-274

Dutz J (1998) Repression of fecundity in the neritic copepod Acartia clausi exposed to the toxic dinoflagellate Alexandrium lusitanicum: relationship between feeding and egg production. Mar Ecol Prog Ser 175:97-107

Edler L (1979) Recommendations on methods for marine biological studies in the Baltic Sea: phytoplankton and chlorophyll. Publication No 5. The Baltic Marine Biologists, Lund

Engström J, Koski M, Viitasalo M, Reinikainen M, Repka S, Sivonen K (2000) Feeding interactions of the copepods Eurytemora affinis and Acartia bifilosa with the cyanobacteria Nodularia sp. J Plankton Res 22:1403-1409

Engström-Öst J, Lehtiniemi M, Green S, Kozlowsky-Suzuki B, Viitasalo M (2002) Does cyanobacterial toxin accumulate in mysid shrimps and fish via copepods? J Exp Mar Biol Ecol 276:95-107

Ferrão-Filho AS, Kozlowsky-Suzuki B, Azevedo SMFO (2002) Accumulation of microcystins by a tropical zooplankton community. Aquat Toxicol 59:201-208

Finni T, Kononen K, Olsonen R, Wallström K (2001) The his- 
tory of cyanobacterial blooms in the Baltic Sea. Ambio 30: 172-178

Fontal OI, Vieytes MR, Baptista de Sousa JMV, Louzao MC, Botana LM (1999) A fluorescent microplate assay for microcystin-LR. Anal Biochem 269:289-296

Frangópulos M, Guisande C, Maneiro I, Riveiro I, Franco J (2000) Short-term and long-term effects of the toxic dinoflagellate Alexandrium minutum on the copepod Acartia clausi. Mar Ecol Prog Ser 203:161-169

Frost BW (1972) Effects of size and concentration of food particles on the feeding behaviour of the marine planktonic copepod Calanus pacificus. Limnol Oceanogr 17:805-815

Hällfors G, Hällfors S (1992) The Tvärminne collection of algal cultures. In: Pokki J (ed) Tvärminne studies, Vol 5. University of Helsinki, p 15-17

Honkanen RE, Codispoti BA, Tse K, Boynton AL (1994) Characterization of natural toxins with inhibitory activity against serine/threonine protein phosphatases. Toxicon 32:339-350

Hughes EO, Gorham PR, Zehnder A (1958) Toxicity of a unialgal culture of Microcystis aeruginosa. Can J Microbiol 4: $225-236$

Jónasdóttir SH, Kiørboe T (1996) Copepod recruitment and food composition: do diatoms affect hatching success? Mar Biol 125:743-750

Jones GJ, Bourne DG, Blakeley RL, Doelle H (1994) Degradation of the cyanobacterial hepatotoxin microcystin by aquatic bacteria. Natural Toxins 2:228-235

Kiørboe T, Sabatini M (1995) Scaling of fecundity, growth and development in marine planktonic copepods. Mar Ecol Prog Ser 120:285-298

Kiørboe T, Møhlenberg F, Hamburger K (1985) Bioenergetics of the planktonic copepod Acartia tonsa: relation between feeding, egg production and respiration, and composition of specific dynamic action. Mar Ecol Prog Ser 26:85-97

Kononen K, Sivonen K, Lehtimäki J (1993) Toxicity of phytoplankton blooms in the Gulf of Finland and Gulf of Bothnia, Baltic Sea. In: Smayda TJ, Shimizu Y (eds) Toxic phytoplankton in the sea. Elsevier Science Publishers, Amsterdam, p 269-273

Koski M (1999) Carbon:nitrogen ratios of Baltic Sea copepods-indication of mineral limitation? J Plankton Res 21:1565-1573

Koski M, Kuosa H (1999) The effect of temperature, food concentration and female size on the egg production of the planktonic copepod Acartia bifilosa. J Plankton Res 21: 1779-1789

Koski M, Engström J, Viitasalo M (1999) Reproduction and survival of the calanoid copepod Eurytemora affinis fed with toxic and non-toxic cyanobacteria. Mar Ecol Prog Ser 188:187-197

Koski M, Schmidt K, Engström-Öst J, Viitasalo M, Jónasdóttir SH, Repka S, Sivonen K (2002) Calanoid copepods feed and produce eggs in the presence of toxic cyanobacteria Nodularia spumigena. Limnol Oceanogr 47:878-885

Kotai J (1972) Instructions for preparation of modified nutrient solution Z8 for algae. B11/69, Norwegian Institute for Water Research, Oslo

Kotak BG, Semalulu S, Fritz D, Prepas EE, Hrudey SE, Coppock RW (1996) Hepatic and renal pathology of intraperitoneally administered microcystin-LR in rainbow trout (Oncorhynchus mykiss). Toxicon 34:517-525

Kurmayer R, Jüttner F (1999) Strategies for the co-occurrence of zooplankton with the toxic cyanobacterium Planktothrix rubescens in Lake Zürich. J Plankton Res 21: 659-683

Lampert W (1987) Laboratory studies on zooplankton-cyano- bacteria interactions. NZ J Mar Freshw Res 21:483-490 Lawton LA, Edwards C, Codd GA (1994) Extraction and high performance liquid chromatography method for the determination of microcystins in raw and treated waters. Analyst 119:1525-1530

Lehtimäki J, Sivonen K, Luukkainen R, Niemelä SI (1994) The effects of incubation time, temperature, light, salinity, and phosphorus on growth and hepatotoxin production by Nodularia strains. Arch Hydrobiol 130:269-282

Lehtimäki J, Lyra C, Suomalainen S, Sundman P, Rouhiainen L, Paulin L, Salkinoja-Salonen M, Sivonen S (2000) Characterization of Nodularia strains, cyanobacteria from brackish waters, by genotypic and phenotypic methods. Int J Syst Evol Microbiol 50:1043-1053

Lehtiniemi M, Engström-Öst J, Karjalainen M, KozlowskySuzuki B, Viitasalo M (2002) Fate of cyanobacterial toxins in the pelagic food web: transfer to copepods or to faecal pellets? Mar Ecol Prog Ser 241:13-21

Magalhães VF, Soares RM, Azevedo SMFO (2001) Microcystin contamination in fish from the Jacarepaguá Lagoon (Rio de Janeiro, Brazil): ecological implication and human health risk. Toxicon 39:1077-1085

Maneiro I, Frangópulos M, Guisande C, Fernández M, Reguera B, Riveiro I (2000) Zooplankton as a potential vector of diarrhetic shellfish poisoning toxins through the food web. Mar Ecol Prog Ser 201:155-163

Matthiensen A, Metcalf JS, Ferreira AHF, Yunes JS, Codd GA (2000) Biodegradation and biotransformation of microcystins by aquatic microbes in estuarine waters from the Patos Lagoon, RS, Brazil. In: Koe WJ, Samson RA, van Egmond HP, Gilbert J, Sabino M (eds) Proc Xth Int IUPAC Symp Mycotoxins and Phycotoxins. Ponsen \& Looyen, Wageningen, p 527-536

Metcalf JS, Beattie KA, Pflugmacher S, Codd GA (2000) Immuno-crossreactivity and toxicity assessment of conjugation products of the cyanobacterial toxin, microcystinLR. FEMS Microbiol Lett 189:155-158

Meyer-Harms B, Reckermann M, Voß M, Siegmund H, von Bodungen B (1999) Food selection by calanoid copepods in the euphotic layer of the Gotland Sea (Baltic Proper) during mass occurrence of $\mathrm{N}_{2}$-fixing cyanobacteria. Mar Ecol Prog Ser 191:243-250

Müller-Navarra DC, Brett MT, Liston AM, Goldman CR (2000) A highly unsaturated fatty acid predicts carbon transfer between primary producers and consumers. Nature 403:74-77

Nandini S (2000) Responses of rotifers and cladocerans to Microcystis aeruginosa (Cyanophyceae): a demographic study. Aquat Ecol 34:227-242

Peres-Neto PR (1999) How many statistical tests are too many? The problem of conducting multiple ecological inferences revisited. Mar Ecol Prog Ser 176:303-306

Pflugmacher S, Wiegand C, Oberemm A, Beattie KA, Krause E, Codd GA, Steinberg CEW (1998) Identification of an enzymatically formed glutathione conjugate of the cyanobacterial hepatotoxin microcystin-LR: the first step of detoxication. Biochim Biophys Acta 1425:527-533

Reinikainen M, Lindvall F, Meriluoto JAO, Repka S, Sivonen K, Spoof L, Wahlsten M (2002) Effects of dissolved cyanobacterial toxins on the survival and egg hatching of estuarine calanoid copepods. Mar Biol 140:577-583

Rolff C (2000) Seasonal variation in $\delta^{13} C$ and $\delta^{15} N$ of sizefractionated plankton at a coastal station in the northern Baltic proper. Mar Ecol Prog Ser 203:47-65

Roy S, Harris RP, Poulet AS (1989) Inefficient feeding by Calanus helgolandicus and Temora longicornis on Coscinodiscus wailesii: quantitative estimation using chloro- 
phyll-type pigments and effects on dissolved free amino acids. Mar Ecol Prog Ser 52:145-153

Schmidt K, Jónasdóttir SH (1997) Nutritional quality of two cyanobacteria: how rich is 'poor' food? Mar Ecol Prog Ser 151:1-10

Schmidt K, Kähler P, von Bodungen B (1998) Copepod egg production rates in the Pomeranian Bay (southern Baltic Sea) as a function of phytoplankton abundance and taxonomic composition. Mar Ecol Prog Ser 174:183-195

Sellner KG, Olson MM, Olli K (1996) Copepod interactions with toxic and non-toxic cyanobacteria from the Gulf of Finland. Phycologia (Suppl 6) 35:177-182

Sipiä VO, Kankaanpää HT, Flinkman J, Lahti K, Meriluoto JAO (2001a) Time-dependent accumulation of cyanobacterial hepatotoxins in flounders (Platichthys flesus) and mussels (Mytilus edulis) from the northern Baltic Sea. Environ Toxicol 16:330-336

Sipiä V, Kankaanpää H, Lahti K, Carmichael WW, Meriluoto J (2001b) Detection of nodularin in flounders and cod from the Baltic Sea. Environ Toxicol 16:121-126

Sivonen K, Jones G (1999) Cyanobaterial toxins. In: Chorus I, Bartram J (eds) Toxic cyanobacteria in water: a guide to their public health consequences, monitoring and management. E \& FN Spon, London, p 41-111

Stoecker DK, Egloff DA (1987) Predation by Acartia tonsa Dana on planktonic ciliates and rotifers. J Exp Mar Biol Ecol 110:53-68

Stoecker DK, McDowell Capuzzo J (1990) Predation on Protozoa: its importance to zooplankton. J Plankton Res 12: 891-908

Svensson S (2000) Depuration of diarrhetic shellfish toxins (DST) from mussels, Mytilus edulis: no evidence that food increases the rate of depuration. Abstracts Int Conf Harmful Algal Blooms, Tasmania, p 60

Tang KW, Dam HG (2001) Phytoplankton inhibition of copepod egg hatching: test of an exudates hypothesis. Mar Ecol Prog Ser 209:197-202

Teegarden GJ, Cembella AD (1996) Grazing of toxic dinoflagellates, Alexandrium spp., by adult copepods of coastal Maine: implication for the fate of paralytic shellfish toxins in marine food webs. J Exp Mar Biol Ecol 196:145-176

Editorial responsibility: Otto Kinne (Editor),

Oldendorf/Luhe, Germany
Teegarden GJ, Cembella AD (2000) Assimilation and retention of PSP toxins by zooplankton grazers, with implications for their role as toxin vectors. Abstracts Int Conf Harmful Algal Blooms, Tasmania, p 231

Tester PA, Turner JT (1990) How long does it take copepods to make eggs? J Exp Mar Biol Ecol 141:169-182

Tester PA, Turner JT, Shea D (2000) Vectorial transport of toxins from the dinoflagellate Gymnodinium breve through copepods to fish. J Plankton Res 22:47-61

Thostrup L, Christoffersen K (1999) Accumulation of microcystin in Daphnia magna feeding on toxic Microcytis. Arch Hydrobiol 145:447-467

Turner JT, Doucette GJ, Powell CL, Kulis DM, Keafer BA, Anderson DM (2000) Accumulation of red tide toxins in larger size fractions of zooplankton assemblages from Massachusetts Bay, USA. Mar Ecol Prog Ser 203:95-107

Turner JT, Ianora A, Miralto A, Laabir M, Esposito F (2001) Decoupling of copepod grazing rates, fecundity and egghatching success on mixed and alternating diatom and dinoflagellate diets. Mar Ecol Prog Ser 220:187-199

Turriff N, Runge JA, Cembella AD (1995) Toxin accumulation and feeding behaviour of the planktonic copepod Calanus finmarchicus to the red-tide dinoflagellate Alexandrium excavatum. Mar Biol 123:55-64

Ward CJ, Lee EYC, Beattie KA, Codd GA (1998) Colorimetric protein phosphatase inhibition assay for microcystins and nodularin in laboratory cultures and natural blooms of cyanobacteria. In: Reguera B, Blanco J, Fernández ML, Wyatt T (eds) Proc VIII Int Conf Harmful Algae. Xunta de Galicia and Intergovernmental Oceanographic Commission of UNESCO, Paris, p 541-544

Watanabe MM, Kaya K, Takamura N (1992) Fate of toxic cyclic heptapeptides, the microcystins, from blooms of Microcystis (Cyanobacteria) in a hypertrophic lake. J Phycol 28:761-767

White AW (1981) Marine zooplankton can accumulate and retain dinoflagellate toxins and cause fish kills. Limnol Oceanogr 26:103-109

Yoon WD, Schim MB, Choi JK (1998) Description of the developmental stages in Acartia bifilosa Giesbrecht (Copepoda: Calanoida). J Plankton Res 20:923-942

Submitted: May 8, 2002; Accepted: December 3, 2002

Proofs received from author(s): February 25, 2003 